\title{
Hegemoni Bahasa Bugis Terhadap Interaksi Sosial Masyarakat Kelurahan Olo-Oloho Kabupaten Kolaka Utara
}

\author{
Jamaluddin Arifin \\ Program Studi Pendidikan Sosiologi, Fakultas Keguruan dan Ilmu Pendidikan \\ Universitas Muhammadiyah Makassar \\ Email: jamaluddinarifin@unismuh.ac.id
}

\begin{abstract}
Abstrak
Penelitian ini bertujuan mengkaji hegemoni bahasa bugis terhadap interaksi sosial masyarakat Kelurahan Olo-Oloh Kabupaten Kolaka Utara. Jenis penelitian yang digunakan adalah kualitatif dengan pendekatan fenomenologi. Data dikumpulkan melalui observasi, wawancara dan dokumentasi. Keabsahan data dalam penelitian ini melalui Trianggulasi sember, waktu dan teori. Hasil dari penelitian ini menunjukkan bahwa Etnis Bugis sebagai masayarakat pendatang di Kelurahan Olo-Oloho memilki semangat rantau yang sangat besar sehingga mampu bertahan sehingga menjadi bagian dari sistem sosial. Karakter yang dimiliki etnis bugis dapat diterima oleh penduduk lokal sehingga hegemoni bahasa bugis cukup besar terhadap bahasa penduduk lokal. Besarnya hegemoni bahasa bugis karena 1) Etnis bugis sebagai penduduk dominan 2) Integrasi sosial etnis bugis sangat kuat 3) Dominasi Etnis Bugis pada sektor ekonomi dan politik.
\end{abstract}

Kata Kunci : Hegemoni; Bahasa Bugis; Etnis Bugis

\begin{abstract}
This study aims to assess the Bugis language hegemony of the social interaction Olo-Oloh Village North Kolaka. The type of research used is qualitative with a phenomenological approach. Data were collected through observation, interviews and documentation. The validity of the data in this study is through triangulation of sources, time and theory. The results of this study indicate that the Bugis ethnic as an immigrant community in the Olo-Oloho Village has a very large overseas spirit so that they are able to survive so that they become part of the social system. The character possessed by the Bugis ethnicity can be accepted by the local population so that the hegemony of the Bugis language is quite large against the language of the local population. The magnitude of the hegemony of the Bugis language is due to 1) Bugis ethnicity as the dominant population 2) Bugis ethnic integration is very strong 3) Bugis ethnic domination in the economic and political sectors.
\end{abstract}

Keywords : Hegemony; Bugis Language; Bugis Ethnicity 


\section{PENDAHULUAN}

Studi tentang interaksi sosial telah banyak dikaji dan diteliti oleh kalangan ilmuan sosiolog, dan penggiat ilmu sosial. Interaksi sosial merupakan hal yang paling mendasar dalam kehidupan bermasyarakat. Interaksi sosial dapat didefinisikan sebagai hubungan dan pengaruh timbal balik antara individu dengan individu, individu dengan kelompok, kelompok dengan kelompok. Interaksi sosial merupakan bentuk dari dinamika sosial budaya yang ada dalam masyarakat. Interaksi sosial akan memungkinkan terjadinya perubahanperubahan di dalam masyarakat yang akan membentuk hal-hal yang baru yang membuat dinamika masyarakat menjadi hidup, perubahan-perubahan ini akan terjadi sambung-menyambung dari generasi yang satu ke generasi berikutnya sepanjang zaman. Walgito (2007) mengemukakan interaksi sosial adalah hubungan antara individu satu dengan individu lain, individu satu dapat mempengaruhi individu yang lain atau sebaliknya, sehingga terdapat hubungan yang saling timbal balik. Hubungan tersebut dapat terjadi antara individu dengan individu, individu dengan kelompok atau kelompok dengan kelompok. Adapun Basrowi (2015) mengemukakan interaksi sosial adalah hubungan dinamis yang mempertemukan orang dengan orang, kelompok dengan kelompok, maupun orang dengan kelompok manusia. Bentuknya tidak hanya bersifat kerjasama, tetapi juga berbentuk tindakan, persaingan, pertikaian dan sejenisnya.

Salah satu hal yang paling mendukung interaksi sosial adalah bahasa sebagai alat komunikasi. Bahasa merupakan simbol dalam interaksi sosial yang menjadi penentu dalam keberhasilan suatu interaksi yaitu tercapainya kesamaan pengertian dan pandangan tentang suatu hal antara individu-individu yang terlibat interaksi. Dengan demikian, bahasa berfungsi apabila pesan yang disampaikan dapat dimengerti oleh orang lain yang menjadi sasaran (Mirna, 2014). Selain itu bahasa tidak hanya digunakan sebagai alat komunikasi namun memiliki juga pengaruh terhadap bahasa-bahasa lainnya dimana bahasa itu digunakan. Sebagaimana yang terjadi di Kelurahan Olo-Oloho Kabupaten Kolaka Utara sebagai salah satu daerah yang menjadi sasaran urban menjadikan daerah tersebut tidak lagi berada pada formasi social yang simlpitas. Berbagai etnis yang tinggal di Keluraha Olo-Oloho sehingga masyarakatnya sangat heterogen. Heterogenitas masyarakat di Keluraha Olo-Oloho memunculkan kelolpok masyarakat yang dominan dan memberikan pengaruh yang cukup besar terhadap masayarakat lokal. Kelompok masyarakat dominan tersebut adalah Etnis Bugis yang sudah tinggal sejak lama dan telah membentuk suatu kesatuan masyarakat yang integral.

Dominasi Etnis bugis di Kelurahan Olo-Oloho meliputi berbagai sektor kehidupan pada daerah tersebut sehingga mempengaruhi sistem bahasa pada masayarakat lokal.Bahasa daerah msayarakat lokal mengalami keterpinggiran karena hadirnya bahasa bugis yang penggunanya lebih banyak dan sering digunakan mengakibatkan masayarakat lokal berusaha paham dan mempelajari bahasa bugis sebagai bahasa sehari-hari daerah tersebut. Berdasarkan fakta diatas maka penulis melakukan penelitian untuk mengetahui secara mendalam melalui penelitian dengan judul Hegemoni Bahasa Bugis Terhadap Interaksi Sosial Masyarakat Kelurahan Olo-Oloho Kabupaten Kolaka Utara

\section{METODE PENELITIAN}

Jenis penelitian yang digunakan yakni kualitatif dengan pendekatan fenomenologi yang mengkaji dan menganalisis secara tajam Hegemoni Bahasa Bugis terhadap penggunaan 
bahasa daerah masyarakat lokal di Kelurahan Olo-Oloho Kebaupaten Kolaka Utara. Pertimbangan ini sesuai dengan harapan dalam mengfungsikan metode kualitatif agar dapat meyelami permasalahan secara aktif yaitu upaya melalui penalaran pikiran dan perasaan sekaligus berusaha memahaminya secara taksonomikal dimana pada gilirannya mampu menghasilkan proposisi-proposisi tentang formulasi dalam upaya menganalisa kemengapaan pada fokus penelitian. Sebagimana Creswel (2003) menyatakan bahwa, penelitian kualitatif adalah pendekatan untuk membangun pernyataan pengetahuan berdasarkan perspektif konstruktif (contoh: maknamakna yang bersumber dari pengalaman individu, nilai-nilai sosial dan sejarah, dengan tujuan untuk membangun teori atau pola pengetahuan tertentu).

Penelitian ini dilaksanakan di Kelurahan Olo-Oloho Kabupaten Kolaka Utara dengan karakteristik geografisnya merupakan wilayah dataran rendah, \pm 100 meter di atas permukaan laut, persawahan di desa tersebut termasuk sawah tadah hujan. Letak tempat penelitian berada di sebelah barat ibukota kabupaten dengan tipologi termasuk desa persawahan atau desa dataran rendah.

Penelitian ini berfokus pada hegemoni bahasa bugis terhadap bahasa daerah masyarakat lokal di Keluraha OloOloho Kabupaten Kolaka Utara. Untuk mengetahui lebih mendalam hal tersebut, peneliti mengambil data dari informan dengan teknik berantai (snow ball), dari ciri-cirinya seperti: (1) Informan tidak ditarik atau ditentukan terlebih dahulu; (2) Informan dipilih atas dasar fokus penelitian; (3) Informan ditentukan oleh pertimbangan-pertimbangan informasi yang diperlukan, informasi selanjutnya diambil dari petunjuk informan sebelumnya, data atau informasi yang dikumpulkan berakhir pada titik kejenuhan, yaitu jika informasi yang didapatkan telah berulan-ulang dari informan yang berbeda (Moleong, 2012).
Adapun informan yang dimaksud terdiri dari: (1) Pemerintah setempat dalam hal ini Lurah dan beberapa staf kelurahan sebagai informan yang memberikan keterangan terkait tujuan penelitian pertama dan ketiga (2) Kepala Dusun dan beberapa tokoh masyarakat desa sebagai informan yang memberikan keterangan terkait ujuan penelitian pertama dan ketiga (3) Semua lapisan masyarakat baik dari masyarakat lokal maupun masyarakat pendatang yang dianggap peneliti bias memberikan informs yang dibutuhkan dalam penelitian.

Pengumpulan data atau informasi dilakukan langsung oleh peneliti dengan menggunakan tiga teknik yaitu: observasi (pengamatan terlibat), wawancara mendalam (depth interview) dan dokumentasi. Teknik analisis data yang dilakukan dalam penelitian ini adalah secara induktif melalui pengorganisasian data, menjabarkannya ke dalam unit-unit, melakukan sintesa, menyususn ke dalam pola, memilih mana data penting dan membuat kesimpulan. Dalam penelitian ini, teknik pengabsahan data yang penulis gunakan adalah perpanjangan keikutsertaan, ketekunan pengamatan, trianggulasi, pengecekan sejawat, analisis kasus negatif, kecukupan referensi, pengecekan anggota, uraian rinci dan audit trail (Moleong, 2002 ; Sugiyono, 2006)

\section{HASIL DAN PEMBAHASAN}

Berdasarkan data yang diperoleh dilapangan melalui observasi atau pengamatan secara langsung oleh peneliti dilokasi penelitian, wawancara mendalam dengan semua informan ynag memiliki karakteristik berbeda dengan mengacu pada pedoman wawancara yang sifatnya semi struktur dan dokumentasi data dari berbagai sumber tertulis maka peneliti menemukan hasil penelitian yang sangat dinamis. Data atau informasi yang telah dikumpulkan 
kemudian diolah berdasarkan kaidah ilmiah dengan menggunakan metode penelitian kualitatif.

Terkait dengan tujuan penelitian ini yaitu, bagaimana hegemoni bahasa bugis terhadap bahasa pada masyarakat lokal di Kecamatan Olo Oloho Kabupaten Kolaka Utara. Untuk lebih terperincinya hasil yang ditemukan maka, peneliti mengawali pembahasan pada pola interkasi sosial masyarakat setempat karena peneliti menganggap hal tersebut sangat berkaitan erat dengan inti dari tujuan penelitian ini. Selain itu pembahasan terkait dengan interkasi sosial pada masyarakat tersebut adalah bagian integral dari penelitian ini. Berikut pembahasan pola interaksi sosial masyarakat setempat sebagai bagaian dari hasil penelitian ini adalah manusia pada dasarnya dalam melakukan interaksi mempunyai naluri semenjak dilahirkan maupun disosialisasikan dalam kehidupan bermasyarakat maka seseorang individu tentunya membutuhkan individu maupun kelompok lainnya untuk dapat mempertahankan hidup. Interaksi sosial merupakan suatu kunci dari semua kehidupan sosial sebab tanpa adanya interaksi sosial pastinya tak akan mungkin ada kehidupan bersama. Akibat adanya interaksi sosial mengakibatkan terjadinya proses saling mempengaruhi dan tentunya masyarakat bugis mempunyai pola-pola dalam melakukan interaksi sosial di Kelurahan OloOloho. Adapun pola-pola interaksi yang dilakukan masyarakat Bugis yaitu bersifat assoatif dan dissosiatif.

\section{A. Pola Interaksi Sosial Assosiatif}

\section{1) Kerja bakti}

Dalam sebuah masyarakat tentunya memiliki hubungan atau kedekatan dalam melakukan kerja sama yang baik seperti pada masyarakat etnis
Bugis dan masyarakat lokal. Berdasarkan hasil temuan peneliti di lokasi penelitian terkait dengan tujuan penelitian melalui observasi ditemukan beragam informasi. Maka, adapun observasi yang telah dilakukan sendiri oleh peneliti di sekitar lingkungan masyarakat pada hari Jumat pagi yaitu peneliti melihat masyarakat etnis Bugis maupun masyarakat lokal melakukan kerja bakti dan mereka saling bekerja sama membantu satu sama lain tanpa membedakan etnis mereka.

Keesokan harinya peneliti semakin penasaran apakah masyarakat lokal dengan etnis Bugis hanya melakukan kerja sama ketika mereka melaksanakan kerja bakti. Hasil temuan peneliti melihat bahwa masyarakat lokal dan etnis sangat sering melakukan kerja sama bukan hanya pada saat kerja bakti, tetapi peneliti juga melihat pada waktu itu tetangga melakukan kerja sama saling membantu dan tolong-menolong antar tetangga.

Pola interaksi yang dilakukan dalam bentuk kerja sama antara masyarakat etnis Bugis dan masyarakat lokal bukan hanya pada saat kerja bakti tetapi juga pada saat tetangga meminta bantuan sehingga mereka juga ikut serta membantu.

\section{2) Toleransi etnis}

Suatu masyarakat yang berbeda etnis antara masyarakat etnis Bugis dan masyarakat lokal yang walaupun sering melakukan kerja sama tetapi juga terkadang terjadi sebuah pertentangan baik secara individu dngan individu, individu dengan kelompok maupun kelompok dengan kelompok.

Berdasarkan hasil temuan peneliti di lokasi penelitian yang terkait dengan tujuan penelitian melalui observasi tentunya ditemukan beragam informasi. Oleh karena itu adapun observasi yang 
dilakukan sendiri oleh peneliti di dekat rumah Pak BS (48 th) peneliti melihat dan mendengar bahwa terdapat sekumpulan ibu-ibu yang melakukan interaksi sosial yang berbeda etnis, baik etnis Bugis maupun lokal terjadi kesalahpahaman yang diakibatkan masyarakat etnis Bugis dalam melakukan komunikasi sesama etnis Bugis menggunakan bahasa daerah mereka padahal di sekelompok masyarakat tersebut terdapat masyarakat lokal yang sehingga masyarakat lokal merasa terkucilkan karena tidak diajak berkomunikasi, maka untuk menghindari sebuah pertentangan salah satu ibu-ibu yang bernama Ibu BT (52 th) mengatakan bahwa bagusnya mungkin kalau kita melakukan komunikasi untuk tidak memakai bahasa daerah kita karena tidak baik.

Untuk tercapainya keseimbangan dalam melakukan interaksi sosial dalam kaitannya dengan norma dan nilai-nilai dimasyarakat. Toleransi sering terjadi dalam situasi pertentangan sebagai suatu cara untuk menyelesaikan pertentangan tanpa ada pihak yang dirugikan baik masyarakat etnis Bugis maupun dengan masyarakat lokal.

\section{3) Peleburan bahasa Bugis}

Dalam suatu masyarakat di kelurahan Olo-Oloho baik masyarakat etnis Bugis maupun masyarakat lokal dengan mempunyai latar belakang kebudayaan yang berbeda yang saling bergaul secara interaktif bahkan dalam jangka waktu yang lama maka dengan demikian tidak ada perbedaan antara individu maupun perbedaan kelompok. Suatu hubungan yang terjadi dalam melakukan interaksi sosial, baik masyarakat etnis Bugis dengan masyarakat lokal berjalan dengan baik serta saling menghargai kebudayaan masing-masing. Mereka semua berinteraksi tanpa melihat latar belakang mereka yang berbeda etnis.

4) Mempertahankan budaya etnis Bugis

Budaya etnis bugis yang telah melebur pada kebudayaan masyarakat lokal di kelurahan Olo-Oloho Kabupaten Kolaka Utara namun tidak menghilangkan identitas kedua unsur kebudayaan masyarakat setempat walaupun dalam kurun waktu yang lama bahkan telah membentuk suatu sistem sosial yang terintegrasi. Etnis bugis yang telah tinggal cukup lama dan menetap dan bahkan telah melakukan pertalian kekerabatan melaui ikatan perkawinan dengan masyarakat setempat juga menjadi penyebab melanggengnya etnis bugis sebagi penduduk yang menacapkan hegemoninya terhadap masyarakat setempat.

Meleburnya kedua kebudayaan tersebut yakni etnis bugis dengan masyarakat lokal sehingga kondisi sosial masyarakat pada daerah tersebut juga sangatlah dinamis dan kompleks. Khususnya pada sistem bahasa pada kedua etnis diatas mengalami gejala yang melahirkan hegemoni melalui berbagai proses sosial yang kompleks. Etnis bugis yang telah menjadi penduduk dominan pada wilayah tersebut mampu memberikan hegemoni yang cukup besar pada masyarakat lokal melalui penggunaan bahasa sehari-hari. Gejala tersebut tidak bisa dihindari oleh masyarakat lokal karena lemahnya integrasi sosialnya.

Etnis bugis dalam melakukan pola interaksi sosial bersifat dissosiatif yang berupa persaingan yaitu masyarakat Bugis dengan masyarakat lokal bersaing dalam hal berdagang yang kebanyakan pembeli melihat latar belakang kebudayaan penjual tersebut, Tetapi persaingan antara masyarakat Bugis dengan masyarakat lokal berjalan 
dengan baik yang walaupun mempunyai kebudayaan atau etnis yang berbeda, hal ini menunjukkan tidak adanya kontravensi, pertikaian maupun permusuhan diantara masyarakat Bugis dengan masyarakat lokal. Jika dika dikaitkan dengan penelitian terdahulu (Aminah 2015) yaitu pada proses disosiatif bentuk interaksi yang terjadi yaitu hampir tidak pernah terjadi konflik fisik yang terjadi hanyalah konflik non fisik.

\section{B. Hegemoni Bahasa Bugis Terhadap Interaksi Sosial Masyarakat Kelurahan Olo Oloho Kabupaten Kolaka Utara}

Interaksi sosial pada etnis bugis di Kelurahan Olo Oloho Kabupaten Kolaka Utara dengan menggunakan bahasa bugis sebagai simbol atau identitas yang ditunjukkan oleh etnis bugis. Jalinan komunikasi sesama etnis bugis dengan menggunakan bahas bugis sangatlah konsisten dan bahkan diperkuat oleh hadirnya kekuatan-kekuatan sosial yang terbentuk melalui proses sosial pula. Penggunaan bahasa bugis oleh Etnis Bugis sebagai bahasa sehari-hari di Kelurahan Olo Oloho Kabupaten Kolaka Utara tidak hanya sebagai unsur terpenting dalam menjalin interaksi sosial dengan kata lain penentu tercapainya tujuan dari sebuah interaksi sosial akan tetapi sebagai bagian dari penegasan identitas demi mempertahankan warisan kulturalnya ditanah rantau. Konsistensi penggunaan bahasa bugis memberikan efek atau pengaruh yang cukup besar pada daerah tersebut karena mampu memberikan hegemoni pada masyarakat lokal untuk ikut serta mempelajari bahasa bugis dan menggunakannya pula sebagai bahasa sehari-hari. Dapat kita lihat dan amati hampir semua masyarakat lokal telah mengetahui dan bahkan menguasai bahasa bugis. Gejala tersebut kadang kita sulit membedakan antara etnis bugis asli dan masyarakat lokal dari segi penggunaan bahasa. Passifnya penggunaan bahasa bugis oleh masyarakat lokal di Kelurahan Olo Oloho Kabupaten Kolaka Utara sebagai bukti bahwa kuatnya hegemoni bahasa bugis diwilayah tersebut. Sebagaimana dikemukakan oleh Tamrin, 2013 yaitu pemakaian bahasa pada ranah keluarga etnis Bugis menunjukkan bahwa pemakaianbahasa Bugis dalam ranah keluarga bervariasi. Untuk umur 11 sampai 15 tahun pemakaian bahasa Bugis sudah mulai bergeser, umur 16 sampai 27 tahun pemakaian bahasa Bugis masih bertahan, umur 28 sampai 49 tahun pemakaian bahasa bugis masih kuat bertahan demikian juga yang berumur 50 tahun ke atas pemakaian bahasa Bugis masih sangat kuat bertahan. Maka secara konseptual salah satu faktor yang berpengaruh dalam pemilihan bahasa adalah umur karena turut mendukung pemertahanan bahasa Bugis.

Beberapa hal yang memndorong bahasa bugis memberikan hegemoni padamasyarakat dikelurahan Olo-oloho Kabupaten Kolaka Utara yakni: 1) Dominasi Etnis Bugis secara kuantitas mendiami daerah tersebut. Etnis bugis sebagai penduduk yang sangat banyak di kelurahan Olo-Oloho bukan tidak mungkin karena kehadirannya untuk tinggal menetap sudah sangat lama dan telah melakukan pertalian kekerabatan melalui pernikahan dengan masyarakat lokal. Pada gejala sosial yang lain sampai saat ini etnis bugis terus bertambah melalui proses urbanisasi. Banyak factor dapat kita temukan bahwa Kelurahan Olo-Oloho menjadi salah satu tujuan bagi etnis bugis melakukan proses urbanisasi karena memiliki potensi sumber daya alam yang sangat banyak, khusunya bsektor pertanian, 
perkebunan dan perikanan. 2) Integrasi Sosial etnis bugis sangat kuat. Dapat kita lihat semangat rantau etnis bugis salah modal sosial yang dimilki sehingga mampu terus survive ditanah rantau. Semangat rantau tersebut kemudian menjelma menjadi sebuah konsensus yang mampu mengintegrasikan etnis bugis di Kelurahan Olo Oloho Kabupaten Kolaka Utara. Adanya kesamaan rasa sesama etnis bugis ditanah lantau kemudian terkelola secara terorganisir dalam bentuk paguyuban. 3) Dominasi pada sector ekonomi dan politik. Kemampuan etnis bugis malakukan adaptasi sosial, sehingga secara perlahan kemudian mampu mendominasi pada sektor ekonomi melalui perdagangan dan sektor politik. dalam ranah ekonomi, masyarakat Bugis yang ada di Keluarahan Olo-Oloho masih kental dalam melakukan komunikasi sesama masyarakat Bugis dengan menggunakan bahasa daerah mereka. Hal tersebut menunjukkan bentuk kecintaan kepada daerah Bugis. Jika dikorelasikan dengan tindakan sosial yang dikemukakan oleh Max Weber yaitu a.) tindakan rasional bersifat instrumental yang dimana dalam melakukan interaksi sosial ditujukan untuk mencapai suatu tujuan-tujuan yang diinginkan misalkan masyarakat Bugis melakukan interaksi sosial menggunakan bahasa Bugis dalam melakukan inetarksi sosial dengan sesama masyarakat Bugis yaitu untuk mencapai suatu tujuan yang diinginkan, b.) tindakan rasional berdasarkan nilai yaitu dalam melakukan interaksi sosial dengan maksud untuk mendapatkan nilai di masyarakat, misalkan masyarakat Bugis menyapa masyarakat sesama Bugis dengan sopan dan ramah dengan menggunakan bahasa Bugis c.) tindakan afektif yaitu masyarakat Bugis menggunakan sebuah perasaannya untuk melakukan interaksi sosial yang secara spontan kepada masyarakat Bugis lainnya dengan meminta tolong untuk dibantu dengan menggunakan bahasa daerah ataupun dengan bahasa bugis, d.) tindakan tradisional, yang dimana masyarakat Bugis dalam melakukan interaksi sosial masih terbiasa menggunakan bahasa daerah Bugis sendiri. Pada sektor politik etnis bugis memiliki kpercayaan diri yang sangat tinggi sehingga juga mampu mengambil peran pada wilayah pemamngku kebijakan baik itu pada tingkat RT, RW, Kepala Desa/lurah, Camat. Adnya tiga factor diatas sehingga bahasa bugis yang dibawa oleh etnis bugis memberikan hegemoni pada masyarakat lokal.

\section{KESIMPULAN}

Berdasarkan hasil penelitian yang telah didapat terkait dengan hegemoni bahasa bahasa bugis terhadap interaksi sosial masyarakat di Kelurahan OloOloho Kabupaten Kolaka Utara dapat disimpulkan sebagai berikut:

1) Etnis bugis sebagai penduduk dominan

2) Integrasi sosial etnis bugis sangat kuat

3) Dominasi Etnis Bugis pada sektor ekonomi dan politik.

\section{DAFTAR PUSTAKA}

Abdulsyani. 1994. Sosiologi Skematika, Teori dan Terapan. Jakarta: Bumi Aksara.

Amina, Nur. 2015. Interaksi Antar Etnis di Desa Argakencana Suaru Penelitian di Desa Argakencana Kecamatan Toili Kabupaten Banggai.

AW Suranto. 2011. Komunikasi Interpersonal. Yogyakarta: Graha Ilmu. 
Data statistik. 2020. Kabupaten Kolaka Utara

Dwi Narwoko, J dan Suyanto Bagong. 2011. Sosiologi Teks Pengantar Dan Terapan. Jakarta : Kencana.

Jamaluddin, Nasrullah Adon. 2015. Sosiologi Perkotaan. CV Pustaka Setia. Bandung.

Mirna. 2014. Diaspora Suku Bugis Dalam Kajian Interaksi Suku Bugis Dengan Suku Tolaki. Skripsi. UIN Alauddin Makassar.

Moleong, Lexy J. 2012. Metodologi Penelitian Kualitatif. Bandung : PT Remaja Rosdakarya

Muslim, Asrul. 2013. Interaksi Sosial Dalam Masyarakat Multietnis. UIN Alauddin Makassar.

Ritzer, George. 2014. Teori Sosiologi Moderen. Kencana. Prenadamedia Group. Jakarta.

Salim, Izhar, Mukhlis, dkk. 2019. Pola Interaksi Sosial Etnis Bugis Dengan Madura Di Punggur Kecil Kabupaten Kubu Raya.

Sambas, Syukriadi. 2015. Sosiologi Komunikasi. Pustaka Setia. Bandung.

Santoso, Budi dan Irma Winingsih. 2013. Integrasi Multikultural Dalam Masyarakat Multietnis: Strategi Akulturasi Masyarakat Etnis Jawa Cina Dan Arab Keturunan di Wilayah Semarang. UDINUS.

Sugiyono. 2012. Metode Penelitian Kuantitatif Kualitatif dan $R \& D$. Bandung: Alfabeta.

2013. Metode Penelitian

Pendidikan Pendekatan Kuantitatif, Kualitatif, dan R\&D. Bandung. Alfabeta. 